OPEN ACCESS

Edited by:

Youji Wang,

Shanghai Ocean University, China

Reviewed by:

Amaya Albalat

University of Stirling, United Kingdom

Aibin Zhan,

Research Center

for Eco-environmental Sciences

(CAS), China

*Correspondence:

Guangxu Liu

guangxu_liu@zju.edu.cn

Specialty section:

This article was submitted to

Aquatic Physiology,

a section of the journal

Frontiers in Physiology

Received: 17 November 2018 Accepted: 18 March 2019

Published: 03 April 2019

Citation:

Shi W, Han Y, Guan X, Rong J,

Du X, Zha S, Tang Y and Liu G (2019)

Anthropogenic Noise Aggravates

the Toxicity of Cadmium on Some

Physiological Characteristics of the

Blood Clam Tegillarca granosa.

Front. Physiol. 10:377.

doi: 10.3389/fphys.2019.00377

\section{Anthropogenic Noise Aggravates the Toxicity of Cadmium on Some Physiological Characteristics of the Blood Clam Tegillarca granosa}

\author{
Wei Shi, Yu Han, Xiaofan Guan, Jiahuan Rong, Xueying Du, Shanjie Zha, Yu Tang and \\ Guangxu Liu*
}

College of Animal Science, Zhejiang University, Hangzhou, China

Widespread applications of cadmium (Cd) in various products have caused $\mathrm{Cd}$ contamination in marine ecosystems. Meanwhile, human activities in the ocean have also generated an increasing amount of noise in recent decades. Although anthropogenic noise and $\mathrm{Cd}$ contaminants could be present simultaneously in marine environments, the physiological responses of marine bivalve mollusks upon coexposure to anthropogenic noise and toxic metal contaminants, including $\mathrm{Cd}$ remain unclear. Therefore, the combined effects of anthropogenic noise and $\mathrm{Cd}$ on the physiological characteristics of the blood clam Tegillarca granosa were investigated in this study. The results showed that 10 days of coexposure to anthropogenic noise and $\mathrm{Cd}$ can enhance adverse impacts on metabolic processes, as indicated by the clearance rate, respiration rate, ammonium excretion rate, and O:N ratio of $T$. granosa. In addition, both the ATP content, ATP synthase activity and genes encoding important enzymes in ATP synthesis significantly declined after coexposures to anthropogenic noise and $\mathrm{Cd}$, which have resulted from reduced feeding activity and respiration. Furthermore, the expressions of neurotransmitter-related genes (MAO, AChE, and mAChR3) were all significantly down-regulated after coexposure to anthropogenic noise and $\mathrm{Cd}$, which suggests an enhanced neurotoxicity under coexposure. In conclusion, our study demonstrated that anthropogenic noise and Cd would have synergetic effects on the feeding activity, metabolism, and ATP synthesis of T. granosa, which may be due to the add-on of stress responses and neurotransmitter disturbances.

Keywords: anthropogenic noise, cadmium, Tegillarca granosa, physiological characteristics, neurotoxic

\section{INTRODUCTION}

As a byproduct of the zinc, lead and copper refinery, cadmium (Cd) has been recognized as one of the most dangerous toxic metals for many years (Järup, 2003; Kim et al., 2014). The widespread applications of $\mathrm{Cd}$ in both consumer and industrial products, such as plastics, ceramics, glass and vehicle tires, have resulted in the consistent presence of $\mathrm{Cd}$ contamination in marine ecosystems, which was reported to be as high as $50 \mu \mathrm{g} / \mathrm{L}$ in several heavily polluted areas (Vinarao et al., 2014). Due to its intrinsic ionic similarity to calcium, $\mathrm{Cd}$ can be accidentally ingested by marine bivalves 
and enter into their cells through calcium channels (Vercauteren and Blust, 1999; Shi et al., 2018a), which would subsequently provoke a series of physiological responses, such as a decreased filtration rate, a hampered metabolism, and an altered sex ratio (Liu et al., 2014; Peng et al., 2015a; Shi et al., 2016; Wu et al., 2017). More importantly, many researches have proven that the harmful effects of Cd may occur at a much lower concentration than previously estimated (Zhang et al., 2008).

In the last few decades, human activities have not only brought chemical pollution but also generated an increasing amount of anthropogenic noise in both the open ocean and coastal areas (Peng et al., 2015b). Anthropogenic noise emitted from various ways, such as facility construction, resource exploration and maritime transportation, has led to a new type of pollution, noise pollution (Engås et al., 1996; Vasconcelos et al., 2007). Compared with other environmental disturbances, noise pollution is considered to be extremely harmful because of its universal and uncontrollable characteristics (André, 2009). Anthropogenic noise can directly or indirectly affect a wide variety of marine organisms by disturbing their biological processes and physiological functions, including acoustic communication (Codarin et al., 2009), auditory sensitivity (Popper et al., 2005; Codarin et al., 2009), individual behavior (Popper et al., 2003; Bruintjes and Radford, 2013), and population distribution (Lagardère, 1982; Soto et al., 2013). However, to date, only a few acoustic studies have been conducted with marine invertebrates, especially bivalve mollusks (Peng et al., 2015b). Limited studies have shown that exposure to anthropogenic noise could lead to physiological alterations such as hampered metabolism in marine invertebrates (Peng et al., 2016). For example, an altered $\mathrm{O}: \mathrm{N}$ ratio and the expression of metabolism-related genes were detected in razor clams, Sinonovacula constricta, in response to anthropogenic noise at intensities of $\sim 80$ and $\sim 100 \mathrm{~dB}$ re $1 \mu \mathrm{Pa}$ (Peng et al., 2016).

Anthropogenic noise and Cd contaminants could be present simultaneously in marine environments, especially in polluted coastal areas. Inhabiting the coastal zone, many marine bivalve species are often challenged by multiple environmental stressors (Rocha et al., 2015; Shi et al., 2018a,b; Guan et al., 2018). However, to date, little is known about the physiological responses of marine bivalve mollusks upon coexposure to anthropogenic noise and toxic metal contaminants. To the best of our knowledge, only one recent study investigated the synergetic impacts of anthropogenic noise and trace metal contamination in bivalve mollusks (Charifi et al., 2018). The results showed that compared to that of the control without ship noise, coexposure to cargo ship noise $(150 \mathrm{~dB}$ re $1 \mu \mathrm{Pa})$ and waterborne $\mathrm{Cd}(0.5 \mu \mathrm{g} / \mathrm{L})$ led to $58.97 \%$ reduction in bioaccumulation of $\mathrm{Cd}$ in gills and resulted in a decrease in the growth rate of the oyster Magallana gigas (Charifi et al., 2018).

Although it remains unclear in marine invertebrates, since the neuroendocrine alterations were often reported along with the physiological adverse impacts in marine vertebrates (Romano et al., 2004; Anderson et al., 2011), it is generally accepted that noise may cause physiological impacts by affecting the neuroendocrine regulation pathway. Similarly, the neurotoxicity of $\mathrm{Cd}$ has been well studied in a variety of organisms
(Gabbiani et al., 1967; Méndez-Armenta and Ríos, 2007). Therefore, theoretically, coexposure to noise and Cd may show an add-on or an offset effect on the physiological responses, such as metabolism, of an organism through their synergetic impacts on neuroendocrine regulation. However, whether this speculation holds true in bivalve mollusks needs to be verified by empirical data.

As an important aquaculture bivalve species, the blood clam, Tegillarca granosa is naturally distributed in the IndoPacific region (Liu et al., 2014; Shao et al., 2016). Due to its ecological importance in sediment nutrient cycling and ecosystem carbon flow, many studies have been performed on various aspects of T. granosa (Liu et al., 2016; Shi et al., 2017a,b; Zhao et al., 2017). However, the synergetic impacts of noise and $\mathrm{Cd}$ on the metabolism of bivalve mollusks, including blood clams, remain unknown to date. Therefore, to obtain a better understanding of the physiological responses of bivalve mollusks to coexposure to $\mathrm{Cd}$ and simulated anthropogenic noise, the clearance rate, respiration rate, ammonium excretion rate, O:N ratio, ATP content, activities of ATP synthases, activity of AChE, and expression of neurotransmitter- and ATP synthesis-related genes of T. granosa were investigated in this study. The data obtained could help the community to further understand the potential risk of emerging pollution in marine environments.

\section{MATERIALS AND METHODS}

\section{Collection and Acclimation of Bivalves}

Specimens of adult $T$. granosa (mean \pm SE, shell length of $18.23 \pm 1.34 \mathrm{~mm})$ were collected from Yueqing Bay $\left(28^{\circ} 280^{\prime}\right.$ $\mathrm{N}$ and $121^{\circ} 110^{\prime} \mathrm{E}$ ), Zhejiang, China in June 2018. To obtain the background concentration of $\mathrm{Cd}$, seawater was sampled and analyzed in triplicate following the methods described by Shi et al. (2018a). The background concentration of Cd was found to be under the detection limits $<0.01 \mu \mathrm{g} / \mathrm{L})$. After cleaning off the epizoa, clams were acclimatized for 10 days in a $1000 \mathrm{~L}$ indoor tank with filtered seawater (temperature $21.4 \pm 1.2^{\circ} \mathrm{C}, \mathrm{pH} 8.09 \pm 0.03$, salinity $20.7 \pm 0.1 \%$ ) before the experiment. During the acclimation process, the clams were fed twice daily with the microalgae Tetraselmis chuii at a rate of 5\% of the tissue dry weight, and half the volume of the seawater was replaced with fresh filtered seawater daily. No mortality occurred during this experiment.

\section{Exposure Experiments}

$\mathrm{CdCl}_{2}$ (>99\% purity) was purchased from Aladdin Chemical $\mathrm{Co}$, China. Stock solutions were prepared in deionized water at $1 \mathrm{M}$, a concentration high enough to prevent weighing errors and salinity fluctuation during the adding of stock solution to obtain the desired exposure concentrations (Shi et al., 2016). On the basis of previous studies (Chan, 1995), $50 \mu \mathrm{g} / \mathrm{L}$ of $\mathrm{Cd}^{2+}$ was chosen in this study to simulate the Cd concentration in heavily polluted coastal areas. The sound broadcast system was composed of an underwater loudspeaker (UW-30, ElectroVoice $^{\circledR}$, Indiana, United States; frequency response $0.1-10 \mathrm{kHz}$; 
power-handling capacity 30 watts) connected to a power amplifier player (AV-296, SAST ${ }^{\circledR}$, Guangdong, China; powerhandling capacity 150 watts) as described in our previous study (Peng et al., 2016). According to preliminary survey results and reported data (Arveson and Vendittis, 2000; Zou et al., 2004), underwater sound levels of $\sim 70$ and $\sim 100 \mathrm{~dB}$ re $1 \mu \mathrm{Pa}$ were used in this study to simulate sound levels with different degrees of anthropogenic noise input. An ambient aeration sound level of the culture system without any addition of anthropogenic sound input was used as a control. A downloaded pile-driving noise record reported in a previous study was used in this study as the source of anthropogenic sound input (Solan et al., 2016).

In the present study, three experimental groups and one control group were set up as follows: (1) control group without $\mathrm{Cd}$ and anthropogenic sound input, (2) Cd treatment group

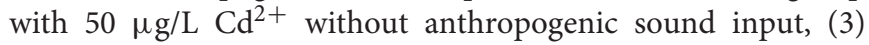
coexposure group with $50 \mu \mathrm{g} / \mathrm{L} \mathrm{Cd}$ and $70 \mathrm{~dB}$ re $1 \mu \mathrm{Pa}$ anthropogenic noise input, and (4) coexposure group with $50 \mu \mathrm{g} / \mathrm{L} \mathrm{Cd}$ and $100 \mathrm{~dB}$ re $1 \mu \mathrm{Pa}$ anthropogenic noise input. After acclimation, 480 clams were randomly assigned to 12 individual $160 \mathrm{~L}$ buckets $(4$ treatments $\times 3$ replicate tanks) containing $50 \mathrm{~cm}$ deep filtered seawater with slight aeration. The submersible loudspeaker was suspended in the center position of the bucket at a depth of $20 \mathrm{~cm}$ below the water surface and oriented to the floor of the bucket to generate the experimental noise effect. The concentrations of $\mathrm{Cd}^{2+}$ in each treatment were measured using a graphite furnace atomic absorption spectrophotometer every 2 days during the experiment, as described previously (Shi et al., 2018a; Table 1). The action acoustic conditions during the experiment were measured using acoustics recording units with a bioacoustics recorder (Song Meter SM2+, Wildlife Acoustics $^{\circledR}$, MA, United States; $96 \mathrm{kHz}$ sampling rate). The working sound pressure levels were measured with a hydrophone near the bottom of the tank at 5, 15, and $25 \mathrm{~cm}$ away from the center (Table 2). Then, acoustic analyses were performed using Soundscape Analysis Software SACS V1.0 (Register number: 2014SR216788) in MATLAB R2013a (The
Math-Works Inc., United States) following the method described previously (Peng et al., 2016). The experiment lasted for 10 days, and no individual mortality was observed throughout the experimental period. The clams were fed with $T$. chuii as mentioned above, and the whole volume of seawater was replaced daily with newly added $\mathrm{Cd}^{2+}$ at the designed concentration after feeding.

\section{Physiological Measurements Clearance Rate}

After 10 days of exposure, the clams were fasted for $12 \mathrm{~h}$ to empty their digestive tracts prior to the clearance rate measurement. Six blood clam individuals from each replicate tank were randomly selected and transported to a $2 \mathrm{~L}$ chamber filled with filtered seawater. Three identical chambers without blood clams were used as the blank control. After approximately 30 min of acclimation, when the valves of the individuals were reopened, the microalgae $T$. chuii was added to the chamber to achieve an initial concentration of $2 \times 10^{5}$ cells $\mathrm{mL}^{-1}$ (Zhao et al., 2017). The experiment lasted for $2 \mathrm{~h}$. The microalgae cell concentrations at the beginning and end of the measurements were counted three times using a Neubauer hemocytometer (XB-K-25, Anxin Optical Instrument) under a microscope (BX53, Olympus, Tokyo, Japan). The microalgae cell concentrations in the control tanks did not show any significant variation during the measurements. After the measurements, the soft tissues of the clams were dissected and dried in an oven at $70^{\circ} \mathrm{C}$ for $72 \mathrm{~h}$. The clearance rate was calculated according to previous studies (Zhao et al., 2017):

$$
C R=V \times\left(\operatorname{Ln} C_{0}-\operatorname{Ln} C_{t}\right) /(W \times T)
$$

where CR represents the clearance rate $\left(\mathrm{L} \mathrm{g}^{-1} \mathrm{~h}^{-1}\right)$; V represents the filtered seawater volume in the chamber $(\mathrm{L}) ; \mathrm{C}_{0}$ represents the initial microalgae concentration (cells $\mathrm{mL}^{-}$); Ct represents the microalgae concentration at time $\mathrm{T}$ (cells $\mathrm{mL}^{-1}$ ); $\mathrm{W}$ represents the dry weight of soft tissues $(\mathrm{g})$; and $\mathrm{T}$ is the experimental time $(\mathrm{h})$.

TABLE 1 | The working sound pressure levels ( $\mathrm{dB}$ re $1 \mu \mathrm{Pa})$ in the experimental setup at different measuring positions.

\begin{tabular}{|c|c|c|c|}
\hline Distance to the center & $5 \mathrm{~cm}$ & $15 \mathrm{~cm}$ & $25 \mathrm{~cm}$ \\
\hline Control & $54.53^{a}(52.77 \sim 57.23)$ & $54.09^{a}$ (52.38 56.73) & $53.45^{\mathrm{a}}(51.90 \sim 55.97)$ \\
\hline Cd treatment & $53.91^{\mathrm{a}}(52.99 \sim 56.74)$ & $53.57^{\mathrm{a}}(52.47 \sim 56.03)$ & $52.95^{\mathrm{a}}(51.75 \sim 55.77)$ \\
\hline $\begin{array}{l}\text { Co-exposure with } 70 \mathrm{~dB} \text { re } 1 \mu \mathrm{Pa} \\
\text { noise input }\end{array}$ & $73.78^{\mathrm{a}}(70.85 \sim 75.09)$ & $72.15^{\mathrm{a}}(69.62 \sim 74.38)$ & $71.52^{\mathrm{a}}(68.79 \sim 73.83)$ \\
\hline $\begin{array}{l}\text { Co-exposure with } 100 \mathrm{~dB} \text { re } 1 \mu \mathrm{Pa} \\
\text { noise input }\end{array}$ & $101.56^{a}(93.55 \sim 108.05)$ & $100.86^{a}(92.89 \sim 107.57)$ & $98.36^{\mathrm{a}}(89.94 \sim 104.37)$ \\
\hline
\end{tabular}

Significant differences at different positions of each experimental setup (data in the same line) are indicated by different superscripts.

TABLE 2 | Waterborne $\mathrm{Cd}^{2+}$ concentrations measured for the different groups.

\begin{tabular}{|c|c|c|c|c|}
\hline Group & Control & Cd treatment & Co-exposure with $70 \mathrm{~dB}$ re $1 \mu \mathrm{Pa}$ noise input & Co-exposure with $100 \mathrm{~dB}$ re $1 \mu \mathrm{Pa}$ noise input \\
\hline Concentration ( $\mu \mathrm{g} / \mathrm{L})$ & Not detected & $49.72 \pm 3.5^{a}$ & $50.21 \pm 4.3^{a}$ & $49.37 \pm 2.66^{a}$ \\
\hline
\end{tabular}

Significant differences are indicated by different superscripts. 


\section{Respiration Rate, Ammonium Excretion Rate, and Oxygen to Nitrogen Ratio}

Six clam individuals were randomly sampled from each bucket after 10 days of exposure. After $12 \mathrm{~h}$ of depuration, these clams were transported into a closed glass respirometer (2 L) filled with oxygen-saturated filtered seawater. After incubation for approximately $30 \mathrm{~min}$, when the valves of the individuals were reopened, the measurements started with the respirometers sealed off for $2 \mathrm{~h}$. Three identical respirometers without clams were used as the blank control. The dissolved oxygen concentrations at the beginning and the end within the respirometers were measured by an oxygen meter (Multi 3410 SET4, WTW, Germany). The concentrations of ammonia produced by the clams were measured by the phenolhypochlorite method (Solórzano, 1969). The dry weight of the soft tissues was obtained as mentioned above. The respiratory rate and ammonium excretion rate of the blood clams were calculated according to the following formula:

$$
\mathrm{R}(\mathrm{E})=\mathrm{V} \times(\mathrm{C} 1-\mathrm{C} 2) /(\mathrm{W} \times \mathrm{T})
$$

where $\mathrm{R}(\mathrm{E})$ represents the respiration (or ammonium excretion) rate $\left(\mathrm{mg} \mathrm{g}^{-1} \mathrm{~h}^{-1}\right) ; \mathrm{V}$ represents the volume of seawater in each respirometer (L); $\mathrm{C}_{1}$ and $\mathrm{C}_{2}$ represent the dissolved oxygen (or ammonia) concentrations $\left(\mathrm{mg} \mathrm{L}^{-1}\right)$ at the beginning and end of the measurement, respectively, $\mathrm{W}$ represents the dry weight of the soft tissues ( $\mathrm{g}$ ); and $\mathrm{T}$ is the experimental time (h). The ratio of oxygen consumption to ammonia excretion expressed as atomic equivalents $(\mathrm{O}: \mathrm{N})$ was calculated to assess the utilization of the different biochemical compositions for energy metabolism (Peng et al., 2016).

\section{Measurements of ATP Content and the Activities of ATP Synthases}

Six clams from each bucket were randomly sampled to determine their ATP contents and the activities of 6-phosphofructokinase (PFK) and pyruvate kinase (PK) in their whole tissues after 10 days of corresponding treatment. A volume of $0.1-0.3 \mathrm{~g}$ of tissue from each individual was homogenized, and then ice-cold saline at quadruple the volume of the tissue was added to each sample. The homogenates were immediately centrifuged at $4^{\circ} \mathrm{C}$ and $2000 \mathrm{r} / \mathrm{min}$ for $10 \mathrm{~min}$. The total protein concentrations of these samples were determined with a commercial kit (P0006, Beyotime Institute of Biotechnology, China) using the Bradford method (Hammond and Kruger, 1988). The collected supernatants were used for the determination of the ATP content and the activities of the ATP synthases.

The amount of ATP in the whole tissue was determined using a commercial ATP assay kit (A095 Nanjing Jiancheng Bioengineering Institute, China) according to the manufacturer's instructions and expressed as $\mu \mathrm{mol}$ per $\mathrm{mg}$ protein. The activities of PFK and PK were measured using commercial kits (A001 and A007, Nanjing Jiancheng Bioengineering Institute, China) with a spectrophotometer (UV-2100, Shanghai Jinghua Instruments, China) at an absorption wavelength of $340 \mathrm{~nm}$ following the manufacturer's protocols. All the enzyme activities were calculated as $U$ per mg protein, where $U$ was defined as the enzyme causing the conversion of $1 \mu \mathrm{mol}$ of substrate $\mathrm{min}^{-1}$.

\section{Determination of AChE Activity}

After 10 days of treatment, five clams from each bucket were used to determine the activity of AChE in their whole tissues. The activity of $\mathrm{AChE}$ was measured using commercial kits (A024, Nanjing Jiancheng Bioengineering Institute, China) with a microplate reader (Thermo Multiskan Go, United States) at an absorption wavelength of $412 \mathrm{~nm}$ and expressed as $U$ per $\mathrm{mg}$ protein, where $\mathrm{U}$ was defined as the amount of enzyme decomposing $1 / 6 \mu \mathrm{mol}$ of substrate per $\mathrm{mg}$ protein per minute at a temperature of $37^{\circ} \mathrm{C}$. The total protein contents of tissues were determined as mentioned above.

\section{Gene Expression Analysis}

The expression levels of the genes encoding the key modulating enzymes or their receptors, including monoamine oxidase (MAO), AChE, and muscarinic acetylcholine receptor M3 (mAChR3), which encode dopamine (DA), acetylcholinesterase (AChE), and ACh receptors, respectively, were investigated in this study (Gainey and Greenberg, 2003; Hermida-Ameijeiras et al., 2004; Guan et al., 2018). Furthermore, the genes encoding the important modulating enzymes in ATP synthesis, including citrate synthase (CS), dihydrolipoamide dehydrogenase (DLD) and 2-oxoglutarate dehydrogenase (SucA), were also examined (Owen et al., 2002; Koubaa et al., 2013). The total RNA was isolated from the gill tissue of 5 individuals from each bucket after 10 days of exposure as described in our previous study (Shi et al., 2017b). The RNA quality and the concentration were verified by gel electrophoresis and a NanoDrop 1000 UV/visible spectrophotometer (Thermo Fisher Scientific, United States), respectively. First strand cDNA was synthesized from high-quality total RNA ( $>500 \mathrm{ng} / \mu \mathrm{L}$ ) using the PrimeScript RT reagent Kit (TaKaRa, RR037A) following the manufacturer's instructions. The amplifications were performed in a total volume of $10 \mu \mathrm{L}$ containing of $5 \mu \mathrm{L}$ of SYBR Green Master Mix (Q111-2, Vazyme, China), $0.2 \mu \mathrm{L}$ of each primer $(10 \mu \mathrm{M}), 0.2 \mu \mathrm{L}$ of ROX Reference Dye (Q111-2, Vazyme, China), $1 \mu \mathrm{L}$ of cDNA template, and $3.4 \mu \mathrm{L}$ of double-distilled water. Real-time quantitative PCR was conducted on the StepOnePlus RealTime PCR System (Applied Biosystems, United States) in triplicate according to the following procedure: $95^{\circ} \mathrm{C}$ for $5 \mathrm{~min}$, followed by 40 cycles $\left(95{ }^{\circ} \mathrm{C}\right.$ for $10 \mathrm{~s}, 60^{\circ} \mathrm{C}$ for $\left.30 \mathrm{~s}\right)$. A melting curve analysis was used to confirm the specificity and reliability of the PCR products. The $18 \mathrm{~S}$ rRNA gene was utilized as an internal reference, and the $2^{-\Delta \Delta \mathrm{CT}}$ method was applied to analyze the relative expression levels of the genes investigated. The primers used are listed in Table 3, and all the primers were synthesized by TsingKe Biotech (Beijing, China).

\section{Statistical Analysis}

One-way ANOVAs followed by Tukey's post hoc tests were conducted to compare the clearance rate, respiration rate, ammonium excretion rate, O:N ratio, ATP content and the activities of the enzymes among the experimental groups. For all the analyses, Levene's test and Shapiro-Wilk's test 
TABLE 3 | Primer sequences for the genes used in the real-time PCR analysis.

\begin{tabular}{|c|c|c|c|}
\hline Gene & Forward primer $\left(5^{\prime}-3^{\prime}\right)$ & Reverse primer $\left(5^{\prime}-3^{\prime}\right)$ & Accession no. \\
\hline MAO & GGTCCTGAACTGTGAGTGTCCTTC & GGATGTCATCGTTATTGGAGGAGGT & $\mathrm{MH} 156850$ \\
\hline AChE & CCTCACTAGGAGTTGTATTGGGTा & CTTGGGAAGATGTGCTTGATGCTA & MH156845 \\
\hline$m A C h R 3$ & GCCCGTGAGTAACTTCCCATAAACA & CCAGACAACATCGTTCTTCGCAAAT & $\mathrm{MH} 156849$ \\
\hline CS & CCCGATACACTTGTCAGAGAGAATT & TTGCCTTGCCTTGTTCTAAGAGTAC & MK170247 \\
\hline$D L D$ & ACGCATGTAACTTCTGCTCCTA & GGTGCCCTGTCGCTAGAGAA & MK170248 \\
\hline SucA & CCTGGTCCACAATCATAGCATGTCT & TTGGATTGGTCAACTGCTGAAGC & MK170249 \\
\hline $18 S$ & СПTСAAATGTCTGCССTATCAACT & TCCCGTATTGTTATIITCGTCACT & JN974506.1 \\
\hline
\end{tabular}

A

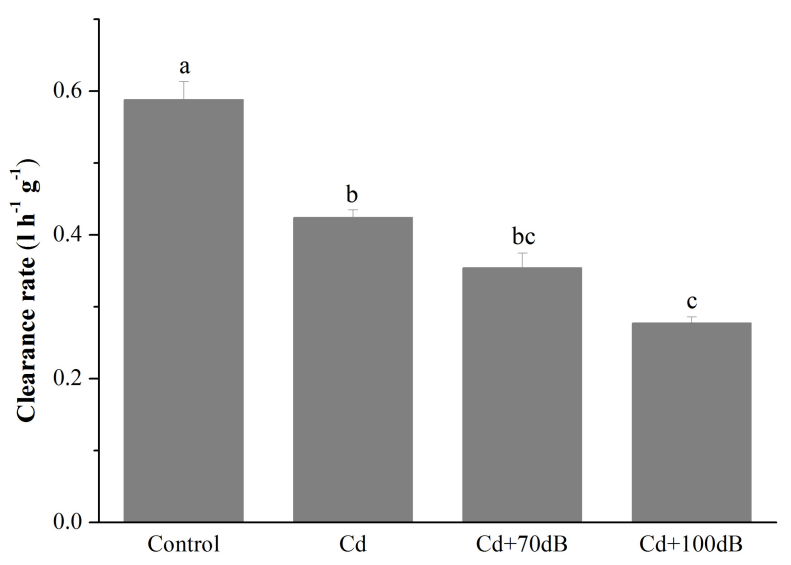

C

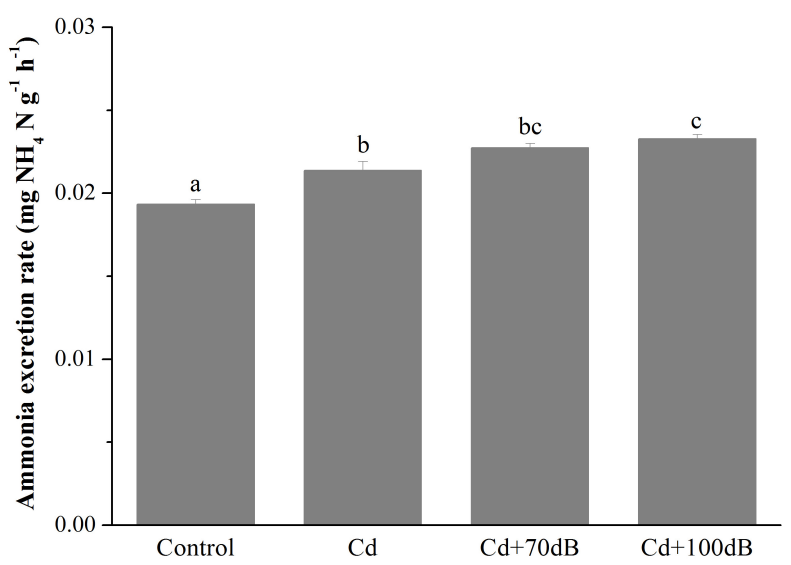

B

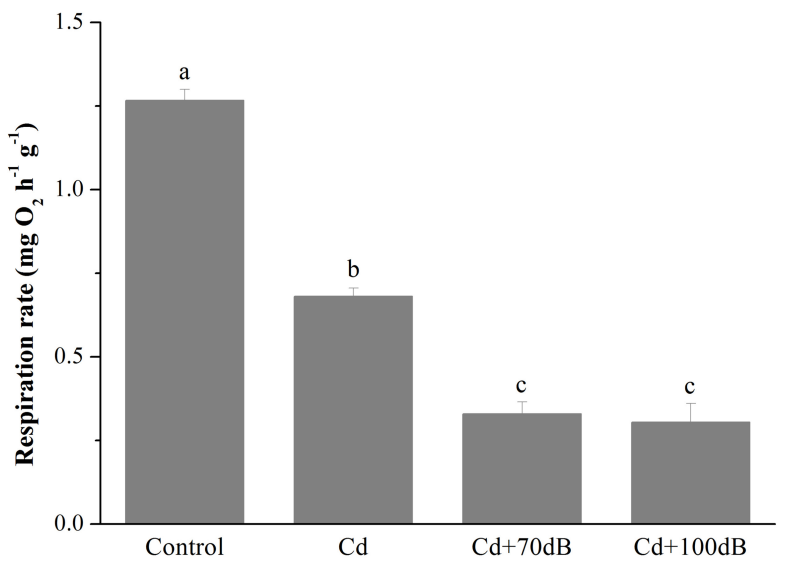

D

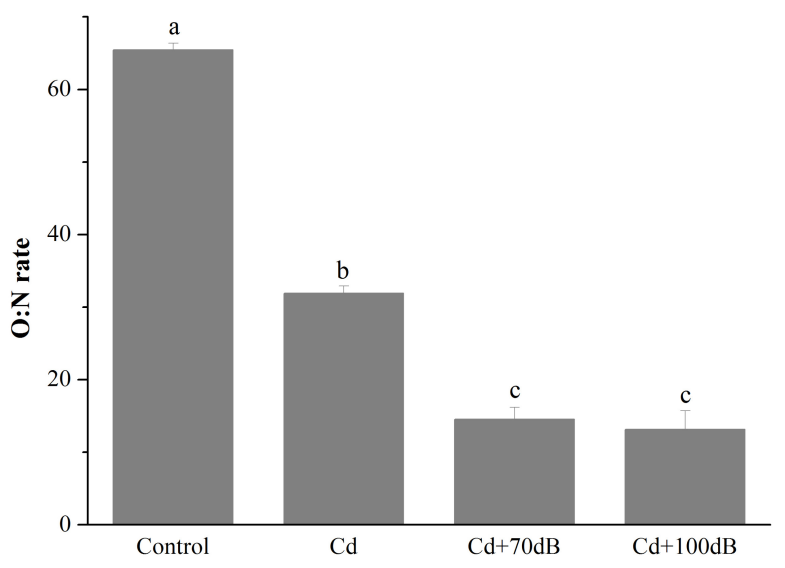

FIGURE 1 | Clearance rates (A), respiration rates (B), ammonium excretion rates (C), and the corresponding oxygen to nitrogen (O:N) ratios (D) of the blood clams after 10 days of exposure to a control (without $\mathrm{Cd}$ and anthropogenic noise), $50 \mu \mathrm{g} / \mathrm{L} \mathrm{Cd}, 50 \mu \mathrm{g} / \mathrm{L} \mathrm{Cd}+70 \mathrm{~dB}$ re $1 \mu \mathrm{Pa}$ anthropogenic noise, and $50 \mu \mathrm{g} / \mathrm{L} \mathrm{Cd}+$ $100 \mathrm{~dB}$ re $1 \mu \mathrm{Pa}$ anthropogenic noise. Means not sharing the same superscript are significantly different.

were used to verify the homogeneity of the variances and normality, respectively. In cases where these assumptions were not satisfied by the raw data, the data were arcsine square root transformed prior to analysis. The gene expression levels were analyzed using the Duncan multiple range test. All the statistical analyses were carried out using the Origin-Pro 8 software package. All of the data are presented as the mean $\pm \mathrm{SE}$, and a $p$-value less than 0.05 indicated a statistically significant difference.

\section{RESULTS}

\section{Metabolic Responses to Cd Exposure and Anthropogenic Noise}

Exposure to $50 \mu \mathrm{g} / \mathrm{L} \mathrm{Cd}$ alone significantly suppressed the clearance rate of the blood clams $(p<0.05)$ (Figure 1A), which was decreased to approximately $72.2 \%$ of that of the control. In addition, coexposure to $\mathrm{Cd}$ and anthropogenic noise led to a further decline in the clearance rates $(p<0.05)$, which were 
reduced to approximately 83.5 and $65.3 \%$ of the $\mathrm{Cd}$ exposure group for coexposure groups with anthropogenic noise at 70 or $100 \mathrm{~dB}$ re $1 \mu \mathrm{Pa}$, respectively.

Similar results were also observed in the respiration rates of the blood clams after 10 days of exposure to $\mathrm{Cd}$ and/or anthropogenic noise (Figure 1B). When exposed to $50 \mu \mathrm{g} / \mathrm{L}$ $\mathrm{Cd}$ alone, the respiration rate dropped to approximately $53.8 \%$ of that of the control. Coexposure to $\mathrm{Cd}$ and anthropogenic noise aggravated the suppression of the respiration rates, which declined to approximately 26.0 and $24.0 \%$ of the control for groups coexposed to $\mathrm{Cd}$ and 70 or $100 \mathrm{~dB}$ re $1 \mu \mathrm{Pa}$ anthropogenic noise, respectively (Figure 1B).

Unlike the clearance rate and respiration rate, the ammonium excretion rates were significantly induced by exposure of the blood clams to $\mathrm{Cd}$ and/or anthropogenic noise $(p<0.05$, Figure 1C). Compared with those of the control, the ammonium excretion rates of the blood clams were significantly elevated to approximately $110 \%$ in seawater with $50 \mu \mathrm{g} / \mathrm{L} \mathrm{Cd}$ and further increased to 118 and $120 \%$ when 70 or $100 \mathrm{~dB}$ re $1 \mu \mathrm{Pa}$ anthropogenic noise was copresent with $\mathrm{Cd}$.

Due to both the reduction in respiration rates and the increase in the ammonium excretion rates, the $\mathrm{O}: \mathrm{N}$ ratios were significantly reduced by $\mathrm{Cd}$ exposure alone and coexposure to $\mathrm{Cd}$ and anthropogenic noise (Figure $1 \mathrm{D}, p<0.05$ ). The $\mathrm{O}: \mathrm{N}$ ratio of clams reduced to approximately $48.7 \%$ of the control when exposed to $50 \mu \mathrm{g} / \mathrm{L} \mathrm{Cd}$ alone for 10 days and further declined to approximately 22.2 and $20.1 \%$ of the control for the groups coexposed to $\mathrm{Cd}$ and 70 or $100 \mathrm{~dB}$ re $1 \mu \mathrm{Pa}$ anthropogenic noise, respectively (Figure 1D).

\section{Effects of $\mathrm{Cd}$ and Anthropogenic Noise Exposure on ATP Content and the Activities of Synthases}

Both exposure of the clams to $\mathrm{Cd}$ alone and coexposure to $\mathrm{Cd}$ and anthropogenic noise significantly reduced the ATP contents of the clams (Figure 2, $p<0.05$ ). After 10 days of exposure to $50 \mu \mathrm{g} / \mathrm{L} \mathrm{Cd}$ alone, the ATP content of the clams was significantly decreased to approximately $77.0 \%$ that of the control. Although the ATP content was not further reduced by the copresence of anthropogenic noise at $70 \mathrm{~dB}$ re $1 \mu \mathrm{Pa}$, coexposure to $100 \mathrm{~dB}$ re $1 \mu \mathrm{Pa}$ anthropogenic noise significantly aggravated the suppression of ATP content compared to that of the group exposed to $\mathrm{Cd}$ alone, which was only approximately $72.9 \%$ of that of the group exposed to Cd alone.

Similarly, compared to that of the control, the activities of PFK and PK significantly declined to approximately 86.4 and $70.6 \%$ of the control, respectively (Figure 3 and $p<0.05$ ) when the clams were exposed to $50 \mu \mathrm{g} / \mathrm{L} \mathrm{Cd}$. Although this suppression effect was not significantly aggravated by the copresence of anthropogenic noise at $70 \mathrm{~dB}$ re $1 \mu \mathrm{Pa}$, the activities of PFK and PK were further reduced to 64.4 and $57.3 \%$ of that of the control for PFK and PK, respectively, when $100 \mathrm{~dB}$ re $1 \mu \mathrm{Pa}$ anthropogenic noise was introduced along with $50 \mu \mathrm{g} / \mathrm{L} \mathrm{Cd}$.

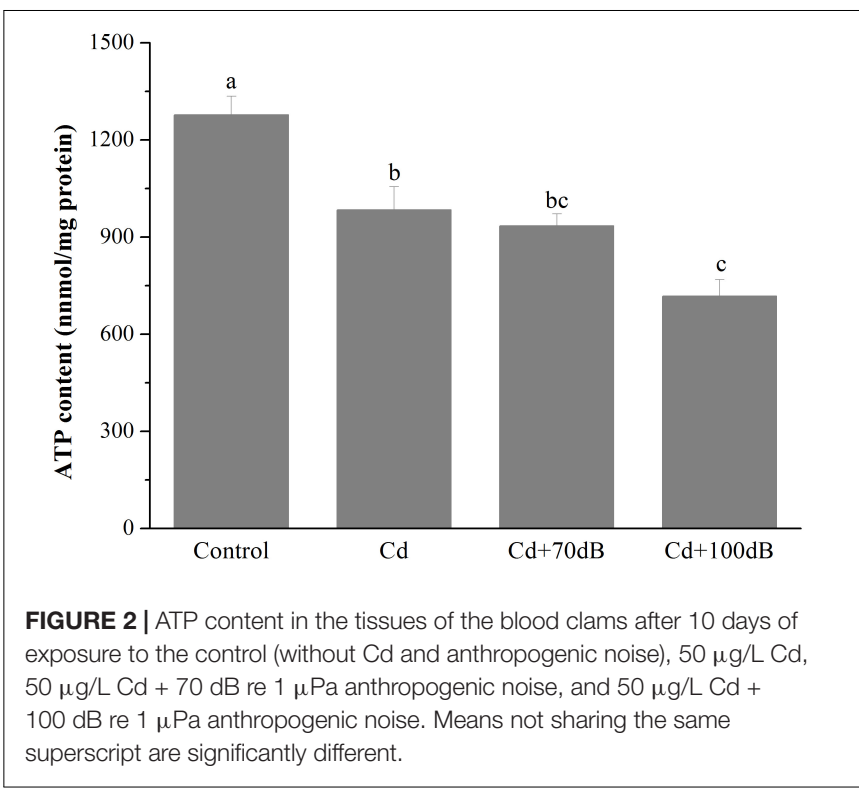

\section{Effects of Cd and Anthropogenic Noise Exposure on the Activity of AChE}

Compared to the control, the activity of AChE in the blood clams was significantly lowered by exposure to $\mathrm{Cd}$ and/or anthropogenic noise for 10 days (Figure 4, $p<0.05$ ). The blood clams exposed to Cd-contaminated seawater had a significantly lower AChE activity, which was approximately $57.9 \%$ of that of the control. However, coexposure to $\mathrm{Cd}$ and anthropogenic noise at 70 or $100 \mathrm{~dB}$ re $1 \mu \mathrm{Pa}$ did not lead to a further reduction in the activity of $\mathrm{AChE}$ when compared to the group exposed to Cd alone.

\section{Effects of Cd and Anthropogenic Noise Exposure on Gene Expression}

All three key genes (CS, SucA, and DLD) encoding enzymes for ATP synthesis showed a similar relative expression pattern, with the highest expression detected in the blood clams of the control followed by those in the Cd exposure group and then the lowest expression in the coexposure groups (Figure 5, $p<0.05$ ). In addition, when coexposed to $\mathrm{Cd}$ and anthropogenic noise, the expression levels of SucA and DLD significantly declined with the increase in sound levels of the anthropogenic noise investigated. Similarly, the downregulation of neurotransmitterrelated genes (MAO, AChE and $\mathrm{mAChR3}$ ) was significantly $(p<0.05)$ aggravated by the copresence of anthropogenic noise (Figure 6, $p<0.05$ ).

\section{DISCUSSION}

As a benthic filter feeder, the blood clam, similar to many other sessile marine bivalves, may be challenged by multiple environmental stressors, such as toxic trace metals and anthropogenic noise (Sokolova et al., 2004; Shi et al., 2016; Peng et al., 2016). Constrained by their limited locomotion ability, 


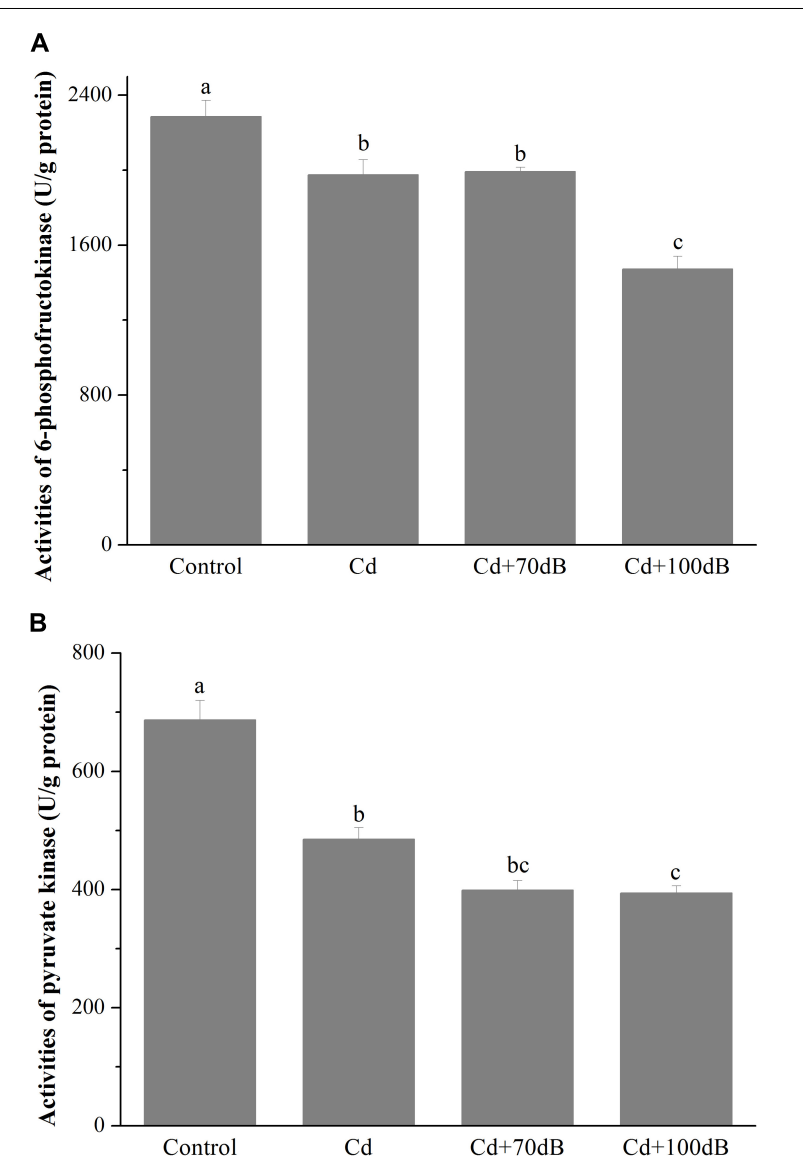

FIGURE 3 | Activities of 6-phosphofructokinase (PFK) (A) and pyruvate kinase (PK) (B) in the tissues of the blood clams after 10 days of exposure to the control (without Cd and anthropogenic noise), $50 \mu \mathrm{g} / \mathrm{L} \mathrm{Cd}, 50 \mu \mathrm{g} / \mathrm{L} \mathrm{Cd}+$ $70 \mathrm{~dB}$ re $1 \mu \mathrm{Pa}$ anthropogenic noise, and $50 \mu \mathrm{g} / \mathrm{L} \mathrm{Cd}+100 \mathrm{~dB}$ re $1 \mu \mathrm{Pa}$ anthropogenic noise. Means not sharing the same superscript are significantly different.

sessile bivalves have difficulty escaping from these stressors and therefore may be potentially threatened by these stressors. However, the physiological responses of bivalve mollusks to coexposure to anthropogenic noise and toxic trace metals are still largely unknown. In addition, little is known about the molecular mechanism manifesting these physiological impacts.

The results obtained in the present study suggested that coexposure to anthropogenic noise and Cd enhances the adverse impacts on metabolic processes, indicated by the clearance rate, respiration rate, ammonium excretion rate, and $\mathrm{O}: \mathrm{N}$ ratio of the marine bivalve mollusks. The reduction in the clearance rate detected indicated that the feeding activity of T. granosa was significantly suppressed. The Cd-induced reduction in feeding activity was also reported in other marine bivalve species, such as the green-lipped mussel Perna canaliculus (Chandurvelan et al., 2012) and the oyster Crassostrea hongkongensis (Pan and Wang, 2012). Furthermore, the result that noise exposure reinforces the suppression of the feeding activity of T. granosa exposed to Cd in the present study may offer

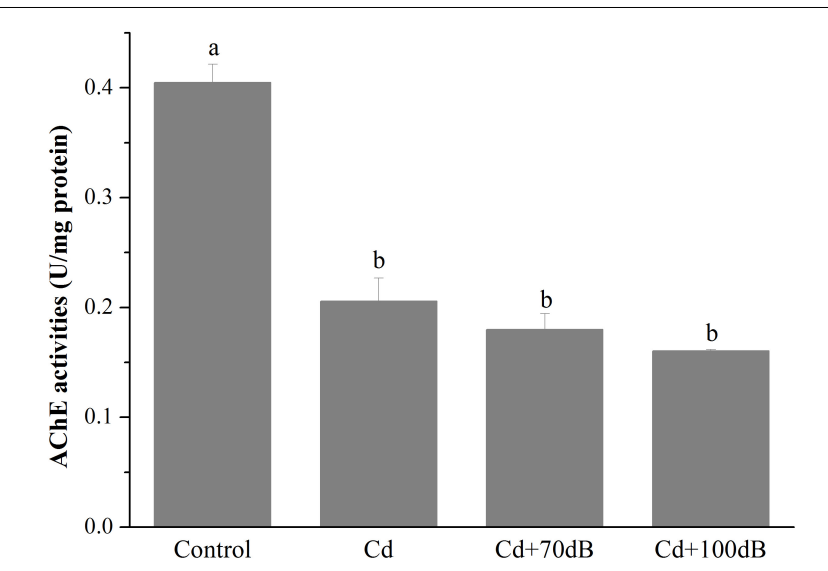

FIGURE 4 | Activities of acetylcholine esterase (AChE) in the tissues of the blood clams after 10 days of exposure to the control (without $\mathrm{Cd}$ and anthropogenic noise), $50 \mu \mathrm{g} / \mathrm{L} \mathrm{Cd}, 50 \mu \mathrm{g} / \mathrm{L} \mathrm{Cd}+70 \mathrm{~dB}$ re $1 \mu \mathrm{Pa}$ anthropogenic noise, and $50 \mu \mathrm{g} / \mathrm{L} \mathrm{Cd}+100 \mathrm{~dB}$ re $1 \mu \mathrm{Pa}$ anthropogenic noise. Means not sharing the same superscript are significantly different.

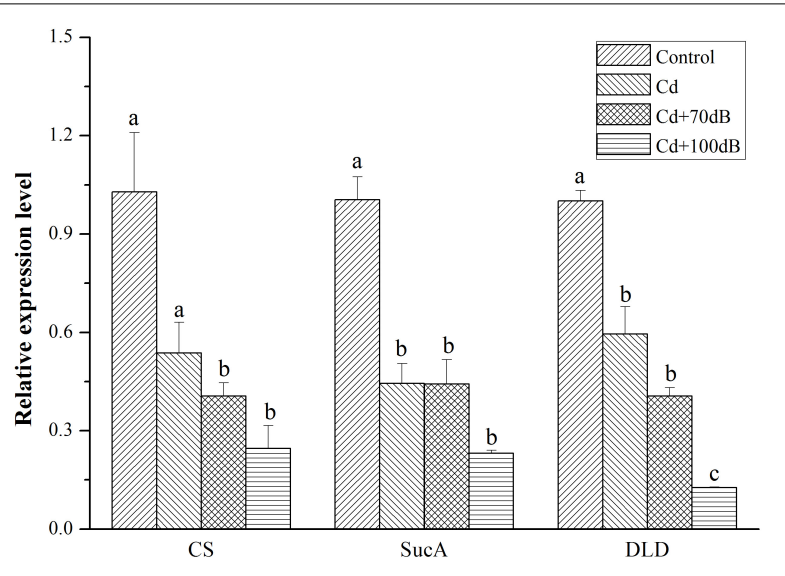

FIGURE 5 | Relative expression levels of the genes in ATP synthesis after 10 days exposure to the control (without $\mathrm{Cd}$ and anthropogenic noise), $50 \mu \mathrm{g} / \mathrm{L}$ $\mathrm{Cd}, 50 \mu \mathrm{g} / \mathrm{L} \mathrm{Cd}+70 \mathrm{~dB}$ re $1 \mu \mathrm{Pa}$ anthropogenic noise, and $50 \mu \mathrm{g} / \mathrm{L} \mathrm{Cd}+$ $100 \mathrm{~dB}$ re $1 \mu \mathrm{Pa}$ anthropogenic noise. Means not sharing the same superscript are significantly different.

an explanation for the reduction in metal accumulation under the noisy scenario reported, since less $\mathrm{Cd}$ will be ingested through feeding (Charifi et al., 2018). In marine bivalves, clearance behavior and respiration are closely linked together, as both processes occur in the water filtration process over the gills during the opening of the valves. It has been shown recently that coexposure to anthropogenic noise and Cd led to an increase in the valve closure duration in the oyster Magallana gigas (Charifi et al., 2018). Therefore, both the reduced clearance and respiration rate obtained in this study can result from the suppression of ventilation (Pan and Wang, 2012).

Due to the reduction in respiration and the increase in ammonium excretion, the O:N ratio of the blood clams was significantly downregulated in response to $\mathrm{Cd}$ and anthropogenic 


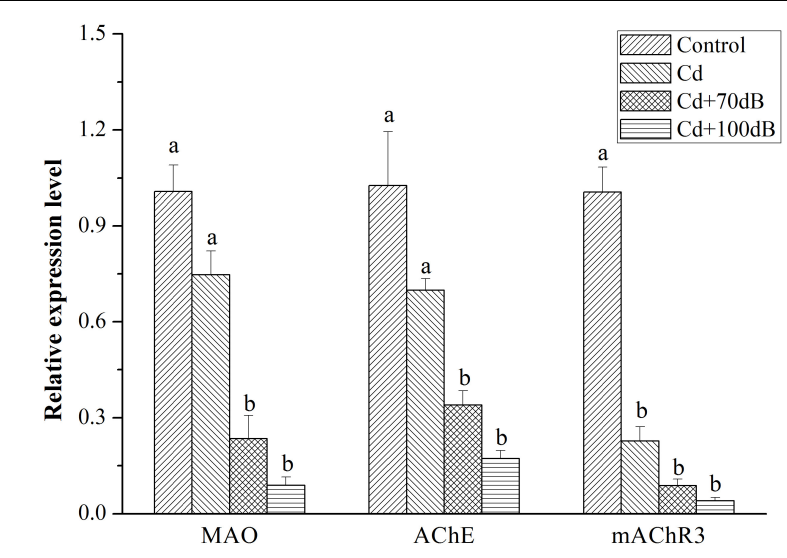

FIGURE 6 | Relative expression levels of the genes encoding neurotransmitter modulatory enzymes and receptors after 10 days of exposure to the control (without Cd and anthropogenic noise), $50 \mu \mathrm{g} / \mathrm{L} \mathrm{Cd,} 50 \mu \mathrm{g} / \mathrm{L} \mathrm{Cd}+70 \mathrm{~dB}$ re $1 \mu \mathrm{Pa}$ anthropogenic noise, and $50 \mu \mathrm{g} / \mathrm{L} \mathrm{Cd}+100 \mathrm{~dB}$ re $1 \mu \mathrm{Pa}$

anthropogenic noise. Means not sharing the same superscript are significantly different.

noise exposures. The O:N ratio is widely considered an indicator of the physiological state of organisms by showing the usage of three substrates (carbohydrates, lipids and proteins) in energy metabolism (Mayzaud and Conover, 1988; Anestis et al., 2010). For example, higher O:N ratios $(<30)$ usually indicate a catabolism of carbohydrates and lipids, while O:N lower ratios $(<30)$ suggest an elevated turnover of proteins under stressful conditions in mussels (Langenbuch and Pörtner, 2002). Therefore, the increase in the ammonium excretion rate along with the reduction in $\mathrm{O}: \mathrm{N}$ ratio detected suggest that more protein substrates were used to provide energy for the clams, and this phenomenon can be due to the declined energy availability through feeding (Sokolova et al., 2005). In this study, both the ATP content and ATP synthase activity in T. granosa significantly declined after stress exposure. In addition, the genes encoding the important enzymes in ATP synthesis were significantly downregulated as well. These ATP synthesis-related results indicated that energy availability was significantly constrained by $\mathrm{Cd}$ and anthropogenic noise exposures, which could be a physiological response to the reductions in feeding activity and respiration.

Reduced metabolism is widely adopted as an adaptive mechanism for marine organisms to cope with various environmental stresses, such as toxic metals, ocean acidification and anthropogenic noise (Pan and Wang, 2012; Peng et al., 2016 Zhao et al., 2017). For example, reductions in feeding and respiration may help in reducing the direct contact of the soft tissues to waterborne chemical contaminants such as toxic metals (Pan and Wang, 2012). Although little is known about the physiological impacts of noise on bivalve mollusks, one study has demonstrated that anthropogenic noise may cause razor clams to enter a metabolically inactive state through sending a stress signal via water proton movement sensed by the sensory palps on the mantle and gills (Peng et al., 2016). Therefore, the additive effects of $\mathrm{Cd}$ and anthropogenic noise on the metabolism of the blood clams could be simply due to the add-on of their inhibitory impacts.

When exposed to stress conditions, the physiological responses of animals are often regulated through the neuroendocrine pathway (Ravindran et al., 2005; Naqvi et al., 2012). Although the neurotoxic impacts of Cd and anthropogenic noise have been well elaborated in model organisms, the impacts remain unclear in bivalve mollusks especially under combined noise and toxic metal stress. The results obtained in the present study demonstrated that anthropogenic noise can enhance the neurotoxicity of waterborne $\mathrm{Cd}$ to bivalves in terms of downregulating the expression of neurotransmitter-related genes. The downregulation of $\mathrm{AChE}$ and $\mathrm{MAO}$, which encode the modulatory enzymes for ACh and DA, respectively, could lead to decreased amounts of modulatory enzymes and subsequently constrain the hydrolysis of the corresponding neurotransmitters (Hermida-Ameijeiras et al., 2004; Guan et al., 2018). It has been confirmed that neurotransmitters play important roles in regulating various physiological functions, such as the feeding activity, of many other organisms (Panksepp and Bishop, 1979; Naqvi et al., 2012). For example, a significant inhibitory effect on food intake was observed in Chinese perch, Siniperca chuatsi, after $1 \mathrm{~h}$ postinjection of $5 \mu \mathrm{g}$ DA ( $\mathrm{He}$ et al., 2018). Therefore, exposure to anthropogenic noise may reinforce the physiological impacts of Cd on blood clams through its synergetic effects on disturbing neurotransmitters.

\section{CONCLUSION}

In conclusion, our study demonstrated that anthropogenic noise and $\mathrm{Cd}$ would have synergetic effects on the feeding activity, metabolism, and ATP synthesis of T. granosa, which may be due to the add-on of stress responses and neurotransmitter disturbances. This study suggests that although $\mathrm{Cd}$ and anthropogenic noise significantly differ in their intrinsic physical and chemical characteristics, the physiological responses provoked are somehow common.

\section{AUTHOR CONTRIBUTIONS}

WS and GL contributed to conception and design of the experimental plan. WS, YH, XG, JR, XD, YT, and SZ performed the experiments. WS and GL performed the statistical analysis and wrote the manuscript.

\section{FUNDING}

This work was funded by National Key R\&D Program of China (2018YFD0900603), National Natural Science Foundation of China (No. 31672634), Open Fund of Key Laboratory for Marine Ecosystem and Biogeochemistry, SOA (No. LMEB201708), and Open Fund of Key Laboratory of Eco-Environment \& Disaster Preservation of Shandong, North China Sea Branch of SOA (No. 201704). 


\section{REFERENCES}

Anderson, P. A., Berzins, I. K., Fogarty, F., Hamlin, H. J., and Guillette, L. J. (2011). Sound, stress, and seahorses: the consequences of a noisy environment to animal health. Aquaculture 311, 129-138. doi: 10.1016/j.aquaculture.2010. 11.013

André, M. (2009). The sperm whale sonar: monitoring and use in mitigation of anthropogenic noise effects in the marine environment. Nucl. Instrum. Meth. A 602, 262-267. doi: 10.1016/j.nima.2008.12.223

Anestis, A., Pörtner, H. O., Karagiannis, D., Angelidis, P., Staikou, A., and Michaelidis, B. (2010). Response of Mytilus galloprovincialis (L.) to increasing seawater temperature and to marteliosis: metabolic and physiological parameters. Comp. Biochem. Physiol. A 156, 57-66. doi: 10.1016/j.cbpa.2009. 12.018

Arveson, P. T., and Vendittis, D. J. (2000). Radiated noise characteristics of a modern cargo ship. J. Acoust. Soc. Am. 107, 118-129. doi: 10.1121/1.428344

Bruintjes, R., and Radford, A. N. (2013). Context-dependent impacts of anthropogenic noise on individual andsocial behaviour in a cooperatively breeding fish. Anim. Behav. 85, 1343-1349. doi: 10.1016/j.anbehav.2013.03.025

Chan, K. M. (1995). Concentrations of copper, zinc, cadmium and lead in rabbitfish (Siganus oramin) collected in Victoria Harbour, Hong Kong. Mar. Pollut. Bull. 31, 277-280. doi: 10.1016/0025-326X(95)00136-B

Chandurvelan, R., Marsden, I. D., Gaw, S., and Glover, C. N. (2012). Impairment of green-lipped mussel (Perna canaliculus) physiology by waterborne cadmium: relationship to tissue bioaccumulation and effect of exposure duration. Aquat. Toxicol. 124-125, 114-124. doi: 10.1016/j.aquatox.2012.07.013

Charifi, M., Miserazzi, A., Sow, M., Perrigault, M., Gonzalez, P., Ciret, P., et al. (2018). Noise pollution limits metal bioaccumulation and growth rate in a filter feeder, the Pacific oyster Magallana gigas. PLoS One 13:e0194174. doi: 10.1371/journal.pone.0194174

Codarin, A., Wysocki, L. E., Ladich, F., and Picciulin, M. (2009). Effects of ambient and boat noise on hearing and communication in three fish species living in a marine protected area (Miramare, Italy). Mar. Pollut. Bull. 58, 1880-1887. doi: 10.1016/j.marpolbul.2009.07.011

Engås, A., Løkkeborg, S., Ona, E., and Soldal, A. V. (1996). Effects of seismic shooting on local abundance and catch rates of cod (Gadus morhua) and haddock )(Melanogrammus aeglefinus). Can. J. Fish. Aquat. Sci. 53, 2238-2249. doi: 10.1139/f96-177

Gabbiani, G., Baic, D., and Déziel, C. (1967). Toxicity of cadmium for the central nervous system. Exp. Neurol. 18, 154-160. doi: 10.1016/0014-4886(67)90037-4

Gainey, L. F., and Greenberg, M. J. (2003). Nitric oxide mediates seasonal muscle potentiation in clam gills. J. Exp. Biol. 206, 3507-3520. doi: 10.1242/jeb.00573

Guan, X., Shi, W., Zha, S., Rong, J., Su, W., and Liu, G. (2018). Neurotoxic impact of acute $\mathrm{TiO} 2$ nanoparticle exposure on a benthic marine bivalve mollusk, Tegillarca granosa. Aquat. Toxicol. 200, 241-246. doi: 10.1016/j.aquatox.2018. 05.011

Hammond, J. B., and Kruger, N. J. (1988). The Bradford method for protein quantitation. Methods Mol. Biol. 3, 25-32. doi: 10.1385/0-89603-126-8:25

He, Y., Li, L., Liang, X., He, S., Zhao, L., and Zhang, Y. (2018). Inhibitory neurotransmitter serotonin and excitatory neurotransmitter dopamine both decrease food intake in Chinese perch (Siniperca chuatsi). Fish Physiol. Biochem. 44, 175-183. doi: 10.1007/s10695-017-0422-8

Hermida-Ameijeiras, Á, Méndez-Álvarez, E. A., Sánchez-Iglesias, S. A., Sanmartı̀̀n-Suárez, C., and Soto-Otero, R. (2004). Autoxidation and MAO-mediated metabolism of dopamine as a potential cause of oxidative stress: role of ferrous and ferric ions. Neurochem. Int. 45, 103-116. doi: 10.1016/j.neuint.2003.11.018

Järup, L. (2003). Hazards of heavy metal contamination. Brit. Med. Bull. 68, 167-182. doi: 10.1093/bmb/ldg032

Kim, E., Jee, J., Steiner, H., Cormet-Boyaka, E., and Boyaka, P. (2014). Chronic exposure to cadmium alters gut immune homeostasis and innate immunity (MUC8P.810). J. Immunol. 192(1 Suppl.), 198.111.

Koubaa, M., Cocuron, J. C., Thomasset, B., and Alonso, A. P. (2013). Highlighting the tricarboxylic acid cycle: liquid and gas chromatography-mass spectrometry analyses of 13 C-labeled organic acids. Anal. Biochem. 436, 151-159. doi: 10.1016/j.ab.2013.01.027

Lagardère, J. P. (1982). Effects of noise on growth and reproduction of Crangon crangon in rearing tanks. Mar. Biol. 71, 177-185. doi: 10.1007/BF00394627
Langenbuch, M., and Pörtner, H. O. (2002). Changes in metabolic rate and N excretion in the marine invertebrate Sipunculus nudus under conditions of environmental hypercapnia. J. Exp. Biol. 205, 1153-1160.

Liu, G., Shu, M., Chai, X., Shao, Y., Wu, H., Sun, C., et al. (2014). Effect of chronic sublethal exposure of major heavy metals on filtration rate, sex ratio, and gonad development of a bivalve species. B. Environ. Contam. Tox. 92, 71-74. doi: 10.1007/s00128-013-1138-9

Liu, S., Shi, W., Guo, C., Zhao, X., Han, Y., Peng, C., et al. (2016). Ocean acidification weakens the immune response of blood clam through hampering the NFK $\beta$ and toll-like receptor pathways. Fish Shellfish Immunol. 54, 322-327. doi: 10.1016/j.fsi.2016.04.030

Mayzaud, P., and Conover, R. (1988). O:N atomic ratio as a tool to describe zooplankton metabolism. Mar. Ecol. Prog. Ser. 45, 289-302. doi: 10.3354/ meps045289

Méndez-Armenta, M., and Ríos, C. (2007). Cadmium neurotoxicity. Environ. Toxicol. Phar. 23, 350-358. doi: 10.1016/j.etap.2006.11.009

Naqvi, F., Haider, S., Batool, Z., Perveen, T., and Haleem, D. J. (2012). Subchronic exposure to noise affects locomotor activity and produces anxiogenic and depressive like behavior in rats. Pharmacol. Rep. 64, 64-69. doi: 10.1016/ S1734-1140(12)70731-4

Owen, O. E., Kalhan, S. C., and Hanson, R. W. (2002). The key role of anaplerosis and cataplerosis for citric acid cycle function. J. Biol. Chem. 277, 30409-30412. doi: 10.1074/jbc.R200006200

Pan, K., and Wang, W. (2012). Reconstructing the biokinetic processes of oysters to counteract the metal challenges: physiological acclimation. Environ. Sci. Technol. 6, 10765-10771. doi: 10.1021/es302040g

Panksepp, J., and Bishop, P. (1979). Neurohumoral and endocrine control of feeding. Psychoneuroendocrino. 4, 89-106. doi: 10.1016/0306-4530(79)90023-4

Peng, C., Zhao, X., Han, Y., Shi, W., Liu, S., and Liu, G. (2015a). Toxic effects of chronic sub-lethal $\mathrm{Cu}^{2+}, \mathrm{Pb}^{2+}$ and $\mathrm{Cd}^{2+}$ on antioxidant enzyme activities in various tissues of the blood cockle, Anadara granosa. J. Res. Sci. Tech. 12, 125-131.

Peng, C., Zhao, X., and Liu, G. (2015b). Noise in the sea and its impacts on marine organisms. Int. J. Environ. Res. Public Health 12, 12304-12323. doi: 10.3390/ijerph121012304

Peng, C., Zhao, X., Liu, S., Shi, W., Han, Y., Guo, C., et al. (2016). Effects of anthropogenic sound on digging behavior, metabolism, $\mathrm{Ca}^{2+} / \mathrm{Mg}^{2+}$ ATPase activity, and metabolism-related gene expression of the bivalve Sinonovacula constricta. Sci. Rep. 6:24266. doi: 10.1038/srep24266

Popper, A. N., Fewtrell, J., Smith, M. E., and Mccauley, R. D. (2003). Anthropogenic sound: effects on the behavior and physiology of fishes. Mar. Technol. Soc. J. 37, 35-40. doi: 10.4031/002533203787537050

Popper, A. N., Smith, M. E., Cott, P. A., Hanna, B. W., Macgillivray, A. O., Austin, M. E., et al. (2005). Effects of exposure to seismic airgun use on hearing of three fish species. J. Acoust. Soc. Am. 117, 3958-3971. doi: 10.1121/1.1904386

Ravindran, R., Rathinasamy, S. D., Samson, J., and Senthilvelan, M. (2005). Noise-stress-induced brain neurotransmitter changes and the effect of Ocimum sanctum (Linn) treatment in albino rats. J. Pharmacol. Sci. 98, 354-360. doi: 10.1254/jphs.FP0050127

Rocha, T. L., Gomes, T., Sousa, V. S., Mestre, N. C., and Bebianno, M. J. (2015) Ecotoxicological impact of engineered nanomaterials in bivalve molluscs: an overview. Mar. Environ. Res. 111, 74-88. doi: 10.1016/j.marenvres.2015. 06.013

Romano, T. A., Keogh, M. J., Kelly, C., Feng, P., Berk, L., Schlundt, C. E., et al. (2004). Anthropogenic sound and marine mammal health: measures of the nervous and immune systems before and after intense sound exposure. Can. J. Fish. Aquat. Sci. 61, 1124-1134. doi: 10.1139/f04-055

Shao, Y., Chai, X., Xiao, G., Zhang, J., Lin, Z., and Liu, G. (2016). Population genetic structure of the blood clam, Tegillarca granosa, along the pacific coast of asia: isolation by distance in the sea. Malacologia 59, 303-312. doi: 10.4002/040.059. 0208

Shi, W., Guan, X., Han, Y., Guo, C., Rong, J., Su, W., et al. (2018a). Waterborne $\mathrm{Cd} 2+$ weakens the immune responses of blood clam through impacting $\mathrm{Ca} 2+$ signaling and $\mathrm{Ca} 2+$ related apoptosis pathways. Fish Shellfish Immunol. 77, 208-213. doi: 10.1016/j.fsi.2018.03.055

Shi, W., Guan, X., Han, Y., Zha, S., Fang, J., Xiao, G., et al. (2018b). The synergic impacts of $\mathrm{TiO} 2$ nanoparticles and $17 \beta$-estradiol (E2) on the immune responses, E2 accumulation, and expression of immune-related genes of the blood clam, 
Tegillarca granosa. Fish Shellfish Immunol. 81, 29-36. doi: 10.1016/j.fsi.2018. 07.009

Shi, W., Han, Y., Guo, C., Zhao, X., Liu, S., Su, W., et al. (2017a). Immunotoxicity of nanoparticle nTiO2 to a commercial marine bivalve species, Tegillarca granosa. Fish Shellfish Immunol. 66, 300-306. doi: 10.1016/j.fsi.2017.05.036

Shi, W., Han, Y., Guo, C., Zhao, X., Liu, S., Su, W., et al. (2017b). Ocean acidification hampers sperm-egg collisions, gamete fusion, and generation of $\mathrm{Ca} 2+$ oscillations of a broadcast spawning bivalve, Tegillarca granosa. Mar. Environ. Res. 130, 106-112. doi: 10.1016/j.marenvres.2017.07.016

Shi, W., Zhao, X., Han, Y., Che, Z., Chai, X., and Liu, G. (2016). Ocean acidification increases cadmium accumulation in marine bivalves: a potential threat to food safety. Sci. Rep. 6:20197. doi: 10.1038/srep20197

Sokolova, I. M., Evans, S., and Hughes, F. M. (2004). Cadmium-induced apoptosis in oyster hemocytes involves disturbance of cellular energy balance but no mitochondrial permeability transition. J. Exp. Biol. 207, 3369-3380. doi: $10.1242 /$ jeb.01152

Sokolova, I. M., Sokolov, E. P., and Ponnappa, K. M. (2005). Cadmium exposure affects mitochondrial bioenergetics and gene expression of key mitochondrial proteins in the eastern oyster Crassostrea virginica Gmelin (Bivalvia: Ostreidae). Aquat. Toxicol. 73, 242-255. doi: 10.1016/j.aquatox.2005.03.016

Solan, M., Hauton, C., Godbold, J. A., Wood, C. L., Leighton, T. G., and White, P. (2016). Anthropogenic sources of underwater sound can modify how sedimentdwelling invertebrates mediate ecosystem properties. Sci. Rep. 6:20540. doi: 10.1038/srep20540

Solórzano, L. (1969). Determination of ammonia in natural waters by the phenolhypochlorite method. Limnol. Oceanogr. 14, 799-801. doi: 10.4319/lo. 1969.14.5.0799

Soto, N. A. D., Delorme, N., Atkins, J., Howard, S., Williams, J., and Johnson, M. (2013). Anthropogenic noise causes body malformations and delays development in marine larvae. Sci. Rep. 3:2831. doi: 10.1038/srep 02831

Vasconcelos, R. O., Amorim, M. C., and Ladich, F. (2007). Effects of ship noise on the detectability of communication signals in the
Lusitanian toadfish. J. Exp. Biol. 210, 2104-2112. doi: 10.1242/jeb. 004317

Vercauteren, K., and Blust, R. (1999). Uptake of cadmium and zinc by the mussel Mytilus edulis and inhibition by calcium channel and metabolic blockers. Mar. Biol. 135, 615-626.

Vinarao, R. T., Salem, G. M., and Ragaza, R. J. (2014). "Distribution of Cd, Pb, As and $\mathrm{Hg}$ in oyster tissue, sediment and water in Lingayen Gulf, Philippines," in Molluscan Shellfish Safety, ed. G. Sauvé (Dordrecht: Springer), 137-154. doi: 10.1007/978-94-007-6588-7_12

Wu, H., Xu, L., Yu, D., and Ji, C. (2017). Differential metabolic responses in three life stages of mussels Mytilus galloprovincialis exposed to cadmium. Ecotoxicology 26, 1-7. doi: 10.1007/s10646-016-1741-8

Zhang, W., Pang, F., Huang, Y., Yan, P., and Lin, W. (2008). Cadmium exerts toxic effects on ovarian steroid hormone release in rats. Toxicol. Lett. 182, 18-23. doi: 10.1016/j.toxlet.2008.07.016

Zhao, X., Shi, W., Han, Y., Liu, S., Guo, C., Fu, W., et al. (2017). Ocean acidification adversely influences metabolism, extracellular $\mathrm{pH}$ and calcification of an economically important marine bivalve, Tegillarca granosa. Mar. Environ. Res. 125, 82-89. doi: 10.1016/j.marenvres.2017.01.007

Zou, C., Chen, D., and Hua, H. (2004). Study on characteristics of ship underwater radiation noise. J. Ship Mech. 8, 113-124.

Conflict of Interest Statement: The authors declare that the research was conducted in the absence of any commercial or financial relationships that could be construed as a potential conflict of interest.

Copyright (c) 2019 Shi, Han, Guan, Rong, Du, Zha, Tang and Liu. This is an openaccess article distributed under the terms of the Creative Commons Attribution License (CC BY). The use, distribution or reproduction in other forums is permitted, provided the original author(s) and the copyright owner(s) are credited and that the original publication in this journal is cited, in accordance with accepted academic practice. No use, distribution or reproduction is permitted which does not comply with these terms. 